\title{
METODE PENGUPAHAN BURUH PETIK KOPI (Studi Kasus Pada Buruh Petik Kopi Di Desa Resapombo )
}

\author{
Endah Masrunik \\ Fakultas Ekonomi Universitas Islam Balitar \\ endahhmasrunik@gmail.com
}

\begin{abstract}
ABSTRAK
Upah adalah merupakan imbalan yang diterima oleh pekerja sesuai kesepakatan atas pekerjaan yang diseleseikan. Tujuan dari penelitian ini untuk mengetahui metode pembayaran upah buruh petik kopi yang ada di Desa Resapombo Kecamatan Doko kabupaten Blitar. Penelitian ini termasuk jenis penelitian kualitatif. Metode penelitian kualitatif adalah suatu pendekatan pada temuan-temuan penelitian yang tidak diperoleh melalui prosedur statistik atau bentuk perhitungan lainnya, tetapi dengan menganalisis dan mendiskriptifkan temuan-temuan secara jelas dan mendalam. Hasil dari penelitian ini diketahui bahwa metode pembayaran upah buruh panen kopi di Desa Resapombo menggunakan beberapa metode yaitu: (1) metode rinjing, dimana upah ditentukan berdasarkan kopi yang diperoleh di takar menggunakan rinjing dengan perbandingan 4:1, 4 rinjing kopi untuk pemilik kopi sedangkan 1 rinjing kopi untuk buruh petiknya. (2)kilon, dimana upah yang diberikan kepada buruh petik berdasarkan jumlah kilogram kopi yang berhasil dipetik. Untuk mendapat upah $1 \mathrm{~kg}$ kopi maka buruh petik harus mampu memetik sebesar 10kg kopi. Sehingga $1 \mathrm{~kg}$ kopi untuk buruh petik dan $9 \mathrm{~kg}$ kopi untuk pemilik.(3) Upah harian, apabila buruh bekerja sehari penuh jam 7 pagi hingga jam 4 sore maka akan menerima upah sebesar Rp.75.000,00. (4)Nyewu, dimana untuk $1 \mathrm{~kg}$ kopi yang berhasil dipetik, buruh mendapatkan upah sebesar Rp.1.000,00.

Kata Kunci: kilon, kopi, kualitatif, nyewu, upah, rinjing
\end{abstract}

\begin{abstract}
Wages are the benefits received by workers according to the agreement for the work completed. The purpose of this study is to determine the method of payment for coffee picking workers' wages in Resapombo Village, Doko District, Blitar Regency. This research is a qualitative research. Qualitative research method is an approach of research's findings that are not obtained through statistical procedures or other forms of calculation, but by analyzing and describing the findings clearly and in depth. The results of this study proves that the payment method for coffee harvest laborers in Resapombo Village uses several methods, namely: (1) the rinjing (a place to carry thing like a bucket made from bamboo) method, where wages are determined based on the coffee obtained by measuring using rinjing with a ratio of 4: 1, 4 rinjing coffee for coffee owners while 1 rinjing coffee for the picking workers. (2) kilons, where the wages given to picking workers are based on the number of kilograms of coffee picked. To earn $1 \mathrm{~kg}$ of coffee, the worker
\end{abstract}


must be able to pick 10kg of coffee. Therefore, that is $1 \mathrm{~kg}$ of coffee for the picking workers and $9 \mathrm{~kg}$ of coffee for the owner. (3) Daily wages, if the worker works a full day from 7 am to $4 \mathrm{pm}$, he receives a wage of Rp.75,000.00. (4) Nyewu, where for $1 \mathrm{~kg}$ of coffee that is successfully picked, the worker is paid Rp.1,000.00.

Key words: kilon/kilogram, coffee, quantitative, nyewu/thousand, wages, rinjing

\section{PENDAHULUAN}

Kopi sebagai salah satu sumber devisa negara memiliki nilai ekonomis yang tinggi dibandingkan dengan hasil perkebunan lainnya (Murtiningrum et al., 2014). Kopi juga merupakan salah satu sumber ekonomi petani di Indonesia (Rahardjo, 2012).Kopi di Indonesia memiliki berbagai jenis dan berada di peringkat ke 4 dunia.Sehingga Indonesia menjadi prioritas untuk pengembangannya.Posisi tersebut menunjukkan bahwa peranan petani kopi dalam perekonomian nasional cukup signifikan. Hal ini juga berarti bahwa keberhasilan pertanian kopi Indonesia secara langsung akan memperbaiki kesejahteraan petani.

Masyarakat petani di pedesaan pada umumnya masih tergolong miskin dan mayoritasnya mengandalkan tenaga kerja sebagai sumber daya utama dalam proses produksi (Toarco et al., 2020). Buruh tani sebagai salah satu komponen pada sektor pertanian, mempunyai kontribusi yang cukup besar dalam menentukan keberhasilan sektor ini.Kenyataan dilapangan menunjukkan bahwa keberhasilan sektor ini tidak selalu diikuti oleh meningkatnya kesejahteraan buruh tani. Hal tersebut disebabkan masih rendahnya upah buruh tani di Indonesia, sementara disisi lain harga barang-barang untuk memenuhi kebutuhan hidup sehari-hari terus meningkat (Kardila et al., 2015). Perkembangan tingkat upah sektor pertanian pun tidak berjalan searah dengan kenaikan harga kebutuhan pokok sehingga berimpliksi negatif terhadap daya beli dan kesejahteraan buruh tani. Rendahnya pendapatan buruh tani juga tidak terlepas dari rendahnya partisipasi dan akses buruh tani terhadap kesempatan kerja diluar sektor pertanian (Suwartapradja, 2008).

Pendapatan buruh tani tidak menentu setiap bulannya karena perhitungan pendapatan mereka tidak menggunakan gaji tetapi menggunakan upah. Gaji dan upah tidaklah sama. Pengertian gaji menurut KBBI didefinisikan sebagai a) upah dari kerja yang dibayarkan dalam waktu yang tetap. b) balas jasa yang diterima oleh perusahaan dalam bentuk uang berdasarkan waktu tertentu. Dari definisi tersebut terlihat bahwa salah satu 
ciri utama gaji adalah dibayarkan dalam waktu tertentu (secara periodik). Pengertian lainnya yaitu gaji adalah pemberian dengan jumlah tetap setiap bulannya kepada pegawai tetap (Larasati, 2018). Gaji merupakan imbalan kepada karyawan dengan jenjang karier atas jasanya (Mulyadi, 2016). Sedangkan upah menurut (Larasati, 2018) adalah imbalan kepada buruh yang melakukan pekerjaan kasar dan lebih banyak menggunakan kekuatan fisik dan biasanya jumlahnya ditetapkan secara harian, satuan atau rombongan dan lazimnya praktik ini ditemukan pada pabrik. Adakalanya upah juga dihitung berdasarkan jumlah produk yang dihasilkan.Jadi dari definisi gaji dan upah di atas kita bisa simpulkan bahwa kalau gaji adalah imbalan lebih kepada atas pikiran dan pikiran yang diberikan dalam tugas yang sifatnya lebih konstan.Dibayarkan dalam jumlah yang tetap dengan sistem pembayaran periodik. Sedangkan upah adalah pembayaran atas penyerahan jasa berdasarkan jumlah pekerjaan (output) yang diselesaikan misalnya dari jumlah jam, jumlah produk jadi, dan sebagainya.

Upah menurut cara pembayarannya kepada buruh tani, di desa-desa yang mempergunakan sistem pengupahan tetap dikenal ada dua macam upah, yaitu upah borongan dan upah harian. Pembayaran upah borongan didasarkan pada satuan hasil kerja.Sedangkan pembayaran upah harian didasarkan pada jumlah hari buruh tani bekerja. Berikut ini merupakan penjelasan yang lebih rinci mengenai upah harian dan upah borongan:

\section{a. Sistem Upah Harian}

Upah harian biasanya diberlakukan untuk pekerjaan yang sifatnya temporer atau yang dapat dilakukan oleh pekerja tidak tetap.Misalnya pekerjaan bangunan, pekerja panen pertanian dan perkebunan.Dalam sistem upah harian, secara teoritis tingkat upah diperhitungkan berdasarkan rata-rata produktivitas tenaga kerja perhari (Susilowati, 2005: 51). Lazimnya jumlah jamkerja per hari antar kegiatan maupun antar desa bervariasi, demikian pula dengan besarnya upah harian.

b. Sistem Upah Borongan

Besarnya upah borongan umumnya sangat tergantung dari prestasi kerja buruh tani.Semakin tinggi produktivitas kerja, secara teoritis semakin tinggi pula upah yang diterima buruh tani (Susilowati, 2005: 52). Variasi produktivitas antar individu buruh tani atau kelompok buruh tani merupakan determinan upah kerja buruh tani. Terdapat beberapa hal yang mendorong munculnya sistem borongan, antara lain: 
1) jadwal tanam secara serentak untuk menghambat serangan hama wereng dan tikus sehingga pengolahan lahan juga harus serentak.

2) sistem pengairan yang semakin baik dan penjadwalan pengairan yang semakin teratur dan ketat memaksa petani untuk mempercepat pengolahan lahan agar dapat melakukan penanaman tepat pada waktunya.

3) penggunaan bibit unggul yang berumur pendek, sehingga pengolahan lahan harus dilakukan dengan cepat.

4) penggunaan traktor dengan upah borongan akan mampu menyelesaikan kegiatan pengolahan tanah dengan cepat, bahkan kurang dari satu hari.

5) pengupahan dengan sistem borongan secara total dinilai lebih murah dibandingkan upah harian, terutama bila nilai makan (termasuk minum dan rokok) buruh tani juga diperhitungkan.

6) tidak merepotkan pemilik lahan karena tidak perlu menyediakan makan. (Susilowati, 2016:51)

\section{METODE PENELITIAN}

Metode penelitian merupakan cara ilmiah yang dilakukan peneliti untuk mendapatkan data dengan tujuan dan kegunaan tertentu (Sugiyono, 2015). Dalam penelitian ini menggunakan metode penelitian kualitatif, yaitu suatu pendekatan penelitian yang tidak menggunakan perhitungan-perhitungan atas temuan penelitiannya.Prosedur ini menghasilkan temuan-temuan yang diperoleh dari data-data yang dikumpulkan dengan menggunakan beragam sarana.Sarana itu meliputi pengamatan, wawancara dan observasi, selain itu juga bisa menggambil dari dokumen, buku, kaset video dan lain sebagainya.

Jenis data dan sumber data dapat digolongkan menjadi dua, yaitu data primer dan data sekunder (Sanusi, 2014). Data primer adalah data yang pertama kali dicatat dan dikumpulkan oleh peneliti, seperti wawancara langsung dengan buruh petik kopi dan petani kopi. Sedangkan data sekunder adalah data yang sudah tersedia dan dikumpulkan oleh pihak lain. Dalam penelitian ini, data sekunder diperoleh dari data kepustakaan yaitu dengan menganalisis buku, jurnal, dan literatur lainnya yang terkait dengan penelitian ini.

Dalam penelitian kualitatif, pemilihan informan merupakan elemen yang sangat penting karena informan akan memberikan data-data yang dibutuhkan peneliti untuk menyelesaikan permasalahan dalam penelitiannya. Teknik purpose digunakan dalam 
pemilihan informan, yaitu teknik pemilihan informan menurut kriteria tertentu sesuai yang telah ditetapkan sesuai dengan topik penelitian.Teknik analisis data yang digunakan dalam penelitian ini adalah analisis kualitatif.Analisis kualitatif deskriptif digunakan untuk menjelaskan hasil penelitian tentang metode pengupahan pada buruh petik kopi di desa Resapombo Kecamatan Doko Kabupaten Blitar.

\section{HASIL DAN PEMBAHASAN}

Desa Resapombo Kecamatan Doko merupakan daerah dataran tinggi sehingga hanya beberapa jenis tanaman yang dapat dikelola masyarakat dengan baik. Diantaranya kopi, cengkeh dan kelapa.Namun mulai saat ini tanaman kopi yang terus meneruh mulai di kembangkan. Hal ini dikarenakan tanaman kopi sangat jarang yang mengalami kematian akibat virus, hanya hama tupai dan luwak yang banyak menyerang tanaman kopi apabila kopi sudah siap panen..

Masa panen kopi hanya setahun sekali namun hasil dari panen tersebut dapat diandalkan oleh masyarakat Desa Resapombo untuk memenuhi kebutuhan hidupnya. Lahan yang mereka garap umumnya adalah lahan warisan dari nenek moyang mereka yang sebelumnya sudah ada tanaman kopinya sehingga mereka hanya tinggal merawatnya saja dan menunggu panen.Namun ada pula yang memulai menanam dari awal.Umur tanaman kopi yang bisa mencapai puluhan tahun dapat menghemat biaya yang dikeluarkan petani karena mereka hanya perlu mengeluarkan biaya untuk perawatan saja.Umur tanaman kopi idealnya adalah 5 sampai 20 tahun namun umur tanaman kopi di desa Resapombo bisa lebih dari 20 tahun. Selama tanaman tersebut masih dapat berbuah maka petani akan terus mengelolanya.

Pendapatan petani kopi di desa Resapombo dipengaruhi oleh beberapa faktor seperti letak dan luas lahan serta kondisi cuaca.Selain itu, faktor lainnya yang mempengaruhi pendapatan petani kopi adalah biaya tenaga kerja yang dikeluarkan.Meskipun pohon kopi tidak memerlukan banyak perawatan, para petani kopi masih tetap mengeluarkan biaya untuk perawatan dan biaya panen kopi.Dengan demikian, pemilik lahan kopi secara tidak langsung juga telah membantu masyarakat yang tidak mempunyai lahan kopi. Mereka yang tidak memiliki lahan kopi dapat memperoleh penghasilan dari upah yang mereka terima atas pekerjaan yang telah mereka lakukan (Suwartapradja, 2008). Pemberian upah kepada buruh panen kopi di desa Resapombo 
Kecamatan Doko Kabuaten Blitar ada empat macam perhitungan yaitu metode rinjing, metode kilon, metode harian dan metode nyewu.

1. Metode Rinjing

Metode rinjing ini merupakan metode pengupahan, dimana upah buruh diberikan berdasarkan banyaknya kopi yang diperoleh kemudian di takar menggunakan rinjing.Rinjing ini merupakan suatu wadah yang terbuat dari anyaman bambu yang mempunyai ukuran agak besar yang berbentuk seperti timba, kalau diukur menggunakan $\mathrm{kg}$ satu rinjimg kopi itu beratnya sekitar 20 sampai $25 \mathrm{~kg}$ kopi.Untuk pemberin upah berdasarkan rinjing ini apabilla pemilik lahan mendapatkan 4 rinjing kopi maka upah yang diterima buruh petik sebesar 1 rinjing kopi. Hal ini sesuai dengan yang dijelaskan oleh mbah Boniyem selaku pemilik lahan kopi sebagai berikut:

“lek ngopahi tak taker gawe rinjing, rinjing iku digawe teko pring lan dinan koyo ember. Yo kiro-kiro sak rinjing kopi iku rongpuluh utowo slawe kilogram. Dadi upahe saben oleh limang ringjing kopi, sing patang rinjing kopi aku, sing sak rinjing kopi sing opek"

Hal tersebut ditegaskan pula oleh bu kantun selaku buruh petik kopi, yang disajikan dalam kutipan wawancara sebagai berikut:

"upah e ditaker rinjing, dadi lek wonge oleh patang rinjing aku oleh sak rinjing. Dadi podo karo papat banding siji"dadi wonge yo ndak rugi, mergo lek gawe rinjingan, sing buruh ndang age age oleh e nyambut gawe ben oleh akeh, lek oleh akeh upah e yo mundak akeh, sing duwe kopi yo demen mergane le nyambut gawe cepet mari geng ndang diopeni meneh ben ndang uwoh meneh"

Berdasarkan pernyatan dari pemilik lahan kopi dan buruh petik kopi tersebut maka pemberiah upah kopi di dasarkan atas banyaknya kopi yang diperoleh kemudian ditakar menggunakan rinjing, dengan perbandingan 4:1 dimana apabila pemilik lahan memperoleh 4 rinjing kopi maka buruh petik akan diberi upah sebanyak 1 rinjing kopi.

Tidak jauh berbeda dengan penelitian (Anam, 2018) yang mengungkapan bahwa besarnya upah yang diberikan didasarkan atas banyaknya kopi yang berhasil dipetik. Namun takarang yang digunakan yatu karung.Dimana setiap 3 karung kopi yang berhasil dipetik maka 2 karung kopi untuk pemilik lahan kopi dan 1 karung kopi untuk buruh petik sebagai upah nya.

Metode rinjing maupun karung, keduannya sangat menguntungkan untuk kedua 
belah pihak. Apabila buruh petik kopi menginginkan upah yang banyak maka mereka harus bekerja lebih giat agar mendapatkan kopi yang semakin banyak, begitu pula untuk pemilik lahan apabila buruh petik bekerja semakin giat maka proses panen kopi bisa cepet selesei dan bisa segera dilakukan perawatan pasca panen agar nantinya kopi yang dihasilkan berkualitas baik (Hafif et al., 2014)

2. Metode Kilon

Untuk metode perkg upah buruh petik kopi dihitung berdasarkan perolehan kopi dan kemudian ditimbang. Dimana apabila buruh petik kopi berhasil memetik $10 \mathrm{~kg}$ kopi maka yang $1 \mathrm{~kg}$ merupakan upah buruh petik kopi dan yang $9 \mathrm{~kg}$ menjadi hak pemilik lahan. Hal ini sesuai dengan ungkapan bapak mesiyan selaku pemilik lahan kopi, yang disajikan dalam kutipan wawancara berikut ini:

"Modele lek ngopahi sing buruh opek kopi yaiku kilon, saben oleh sepuloh kilogram kopi, sing buruh opek tak wei sakkilogram kopi.

Hal senada juga disampaikan oleh Mbak Sri Selaku buruh petik kopi, sebagai berikut:

“opahe opek kopi dkiloni, saben sing duwe kopi sangang kilo aku diwei sakkilo”

Sehingga dari penjelasan yang disampaikan beberapa narasumber tersebut maka dapat disimpulkan bahwa model pengupahan yang digunakan adalah metode kilon dimana tiap $9 \mathrm{~kg}$ kopi untuk pemilik lahan maka buruh petik kopi akan di berikan upah sebesar 1 $\mathrm{kg}$ kopi.

3. Metode Harian

Metode harian merupakan metode pemberian upah dimana besarnya upah dihitung dengan banyaknya hari bekerja. Untuk setiap satu hari kerja, mulai pukul 06.00 pagi sampai pukul 12.00 upah yang didapat sebesar Rp.40.000,00. Hal ini dijelaskan oleh pak Jemani selaku pemilik lahan kopi sebagai berikut:

"kerjone mulai jam enem isuk sampek jam rolas awan. Iku upah e patang puluh ewu.oleh maem pisan"

Hal senada juga disampaikan oleh Bu kantun Selaku buruh petik kopi yang disajikan dalam kutipan wawancara sebagai berikut:

"yo lek kerjone diupah e petangpuluh ewu. Iku mulai kerjo jam enem isuk sampek jam rolas awan lan diwei maem"

Dari penjelasan tersebut dapat dijelaskan bahwa para buruh petik kopi hanya 
bekerja setengah hari. Mereka mulai bekerja pukul 06.00 sampai pukul 12.00 dengan upah sebesar Rp.40.000,00 dan mendapatkan jatah makan satu kali.

Berbeda dengan penelitian (Anam, 2018) upah harian diberikan berupa kopi, dimana 2 hari buruh petik memetik untuk pemilik lahan kemudian 1 hari memetik untuk dirinya sendiri sebagai upahnya.

4. Metode Nyewu

Metode Nyewu merupakan metode dimana $1 \mathrm{~kg}$ kopi yang berhasil dipetik maka buruh petik kopi akan mendapatkan upah sebesar Rp.1000,-. Hal ini sesuai dengan ungkapan bapak Sarju selaku pemilik lahan kopi sebagai berikut”

“ombone papan kopi sekitar sak etar setengah, oleh e sak ton setengah. Sing kerjo wong sepuluh, bendino wong siji kerjone mulai jam enem sampai jam rolas awan. Oleh e kurang luwih setengah kwintalan.Dadi lek unduh rong dinoan cukup.Sak kilone kopi diupahi nyewu. Dadi wong siji bayaran nyatus seketan.

Hal ini senada dengan ungkapan $\mathrm{Bu}$ Tumijem sebagai buruh petik kopi yang disajikan dalam kutipan wawancara sebagai berikut:

"upahe le unduh kopi yo nyewu, tiap sak kilone kopi q dibayar sewu, sedinane ngono kae olehe sekitar skeet kilo jadi bayarane yo skeet ewu”

Dari pernyataan kedua narasumber diatas dapat ditarik kesimpulan bahwa upah buruh petik kopi menggunakan metode nyewu, dimana setiap $1 \mathrm{~kg}$ kopi yang berhasil dipetik, upah yang diberikan kepada buruh petik kopi sebesar Rp.1000,-. Buruh petik kopi bekerja dari pukul 6 pagi hingga pukul 12 siang Dengan kisaran perolehan kopi sehari sebesar $50 \mathrm{~kg} / \mathrm{hari}$. Sehingga tiap buruh petik mampu mengasilkan upah sehari sebesar Rp.50.000,-. Berbeda dengan penelitian Muryadi (2017) yang menyatakan bahwa upah yang diberikan atas $1 \mathrm{~kg}$ kopi yang berhasil dipetik sebesar Rp.450,00 dan setiap 1 pemetik mendapat bagian 1 ancak yang harus diseleseikannya.

\section{KESIMPULAN}

Metode pengupahan dalam bekerja sebagai buruh petik kopi di Desa Resapombo menggunakan beberapa metode yaitu metode rinjing, metode kilon, metode harian dan metode nyewu.metode ini didasarkan atas kebiasaan masyarakat desa resapombo yang menjujung tinggi nilai-nilai kearifan lokal yaitu gotong royong, ikhlas dan saling tolong menolong. 


\section{DAFTAR PUSTAKA}

Haerul Anam. (2018). Tinjaun Hukum Islam Tentang Pemberian Upah Dalam Perjanjian Kerja Panen Biji Kopi Antara pemilik kebun Kopi Dengan Buruh Pemetik Biji Kopi (Studi di Desa Tegal Maja Kecamatan Tanjung Kabupaten Lombok Utara).

Hafif, B., Prastowo, B., \& Prawiradiputra, B. R. (2014). Pengembangan Perkebunan Kopi Berbasis Inovasi Di Lahan Kering Masam. Pengembangan Inovasi Pertanian.

Kardila, J., Erfahmi, \& Sami, Y. (2015). AKTIVITAS PEMETIK KOPI DALAM SENI LUKIS.

Larasati, S. (2018). Manajemen Sumber Daya Manusia. Deepublish.

Mulyadi. (2016). Sistem Akuntansi. In Sistem Akuntansi.

Murtiningrum, F., Asriani, P. S., \& Badrudin, R. (2014). ANALISIS DAYA SAING USAHATANI KOPI ROBUSTA (COFFEA CANEPHORA) DI KABUPATEN REJANG LEBONG. Jurnal AGRISEP. https://doi.org/10.31186/jagrisep.13.1.1-14

Muryadi, A. D. (2017). PRESTASI TENAGA KERJA PANEN KOPI DI PTPN IX KEBUN GETAS AFDELING ASSINAN. 3(1), 1-14.

Rahardjo, P. (2012). Panduan Budidaya dan Pengolahan Kopi Arabika Robusta. In Penebar Swadaya.

Sanusi, A. (2014). Teknik Pengumpulan Data dan Instrumen Penelitian. Metodologi Penelitian.

Sugiyono. (2015). Metode Penelitian. Metode Penelitian.

Susilowati, S. H. (2016). Gejala Pergeseran Kelembagaan Upah pada Pertanian Padi Sawah. Forum Penelitian Agro Ekonomi. https://doi.org/10.21082/fae.v23n1.2005.4860

Suwartapradja, O. S. (2008). Kolektivitas Tenaga Kerja Dalam Pertanian: Studi Tentang Implikasi Curahanh Tenaga Kerja Terhadap ( Labour Force Collectivity in Agriculture: A Study on the Implication of Labour Force O n Farmers' Income in Sumedang Residence ,. Jurnal Kependudukan Padjajaran, 10(1), 34-49.

Toarco, P. T., Di, J., Rantebua, K., \& Toraja, K. (2020). PENGARUH UPAH TERHADAP PRODUKTIVITAS KERJA PEMETIK KOPI PADA. September 2019. 